\title{
Siple Dome shallow ice cores: a study in coastal dome microclimatology
}

\author{
T. R. Jones ${ }^{1}$, J. W. C. White ${ }^{1}$, and T. Popp ${ }^{2}$ \\ ${ }^{1}$ Institute of Arctic and Alpine Research, University of Colorado, Boulder, Colorado, USA \\ ${ }^{2}$ Centre for Ice and Climate, Niels Bohr Institute, University of Copenhagen, Copenhagen, Denmark \\ Correspondence to: T. R. Jones (tyler.jones@colorado.edu)
}

Received: 19 April 2013 - Published in Clim. Past Discuss.: 24 May 2013

Revised: 10 May 2014 - Accepted: 12 May 2014 - Published: 26 June 2014

\begin{abstract}
Ice cores at Siple Dome, West Antarctica, receive the majority of their precipitation from Pacific Ocean moisture sources. Pacific climate patterns, particularly the El Niño-Southern Oscillation (ENSO) and the Southern Annular Mode (SAM), affect local temperature, atmospheric circulation, snow accumulation, and water isotope signals at Siple Dome. We examine borehole temperatures, accumulation, and water isotopes from a number of shallow ice cores recovered from a $60 \mathrm{~km}$ north-south transect of the dome. The data reveal spatial gradients partly explained by orographic uplift, as well as microclimate effects that are expressed differently on the Pacific and inland flanks. Our analyses suggest that while an ENSO and SAM signal are evident at Siple Dome, differences in microclimate and possible postdepositional movement of snow makes climate reconstruction problematic, a conclusion which should be considered at other West Antarctic coastal dome locations.
\end{abstract}

\section{Introduction}

The Siple Dome ice core was drilled as part of the West Antarctic Ice Sheet (WAIS) initiative managed by the National Science Foundation (NSF) Office of Polar Programs (OPP). Originally one of two deep WAIS initiative ice cores (the other being the inland and more elevated WAIS Divide), Siple Dome's coastal location in the Pacific sector of Antarctica was selected in part to study regional climate signals. In this study, we evaluate a series of shallow ice cores drilled at sites across the dome to better characterize small-scale patterns in relationship with local climate variability as well as determine the feasibility of long-term climate reconstruction using coastal ice core sites in West Antarctica (WA).

\subsection{Site description}

Siple Dome is located in WA on the Siple Coast at approximately $81^{\circ} 40^{\prime} \mathrm{S}, 148^{\circ} 49^{\prime} \mathrm{W}$ (Fig. 1). The Siple Coast contains five major ice streams (A-E), which drain part of the WAIS, and is immediately adjacent to the Ross Ice Shelf. Siple Dome is located between ice streams C and D. Drill sites include two cores on the north flank of the dome facing the Pacific Ocean (E and $G$ ), three cores from the summit of the dome (B, C and D), and two cores on the south flank of the dome facing inland ( $\mathrm{H}$ and F) (Fig. 1). The maximum slope across the study area is relatively flat at $7.2 \mathrm{~m} \mathrm{~km}^{-1}$. Table 1 summarizes the details for each ice core location.

\subsection{Antarctic teleconnection}

The Siple Dome region is centrally located to study all of the effects connected to the El Niño-Southern Oscillation (ENSO), the Southern Annular Mode (SAM), and the Amundsen Sea low-pressure area (ASL). Previous studies have shown that teleconnected ENSO climate signals are pervasive across the Antarctic continent (Turner, 2004). In WA, ENSO has been shown to affect atmospheric circulation, local temperature, and snow accumulation (Delaygue et al., 2000; Bromwich et al., 2004; Guo et al., 2004; Schneider et al., 2004). A positive correlation exists between ENSO and the SAM during times of strong teleconnection (Fogt and Bromwich, 2006), such that the SAM index expresses both high-latitude and tropical climate variability (Ding et al., 2012). In turn, the SAM influences the depth of the ASL, and 

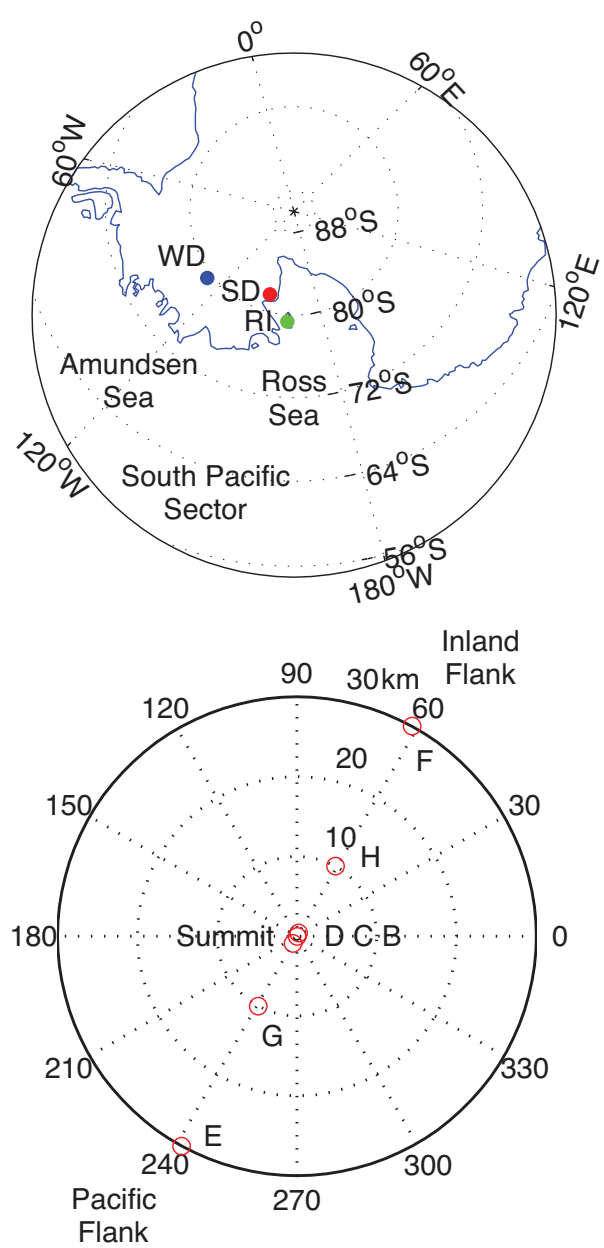

Figure 1. Top panel: map of Antarctica centered on the Ross Sea region. The red dot is Siple Dome (SD), the blue dot is the WAIS Divide (WD), and the green dot is Roosevelt Island (RI). WD and $\mathrm{RI}$ are recently drilled ice cores in close proximity to Siple Dome. Bottom panel: local map of Siple Dome including grid locations of shallow ice cores B-H. The Pacific flank cores are to the north of the dome summit, and the inland flank cores are to the south of the dome summit.

both the location and depth of the ASL affects the climatology of the Ross Sea region and the interior of West Antarctica by influencing storm tracks (Turner et al., 2012).

Research by Hosking et al. (2013) shows that $\sim 25 \%$ of variance expressed in the SAM index is related to ENSO variations. However, the exact location, phasing, and climate forcing of the ASL in relation to ENSO has been the topic of numerous studies. Turner et al. (2012) showed that the ASL is significantly deeper during La Niña as compared to El Niño, but the zonal location of the ASL is not statistically different during either ENSO phase. Bertler et al. (2006) showed that the ASL causes near-surface temperature anomalies in the eastern Ross Sea, resulting in a net cooling during El Niño events and a net warming during La Niña events. Fogt and Bromwich (2006) found that posi-
Table 1. The Siple Dome shallow ice core sites $(\mathrm{B}-\mathrm{H})$ and borehole temperature measurement sites $(\mathrm{G}, \mathrm{B}, \mathrm{H}, \mathrm{J})$ used in this study.

\begin{tabular}{llllcc}
\hline Site & Data type & $\begin{array}{l}\text { Latitude } \\
\text { (degrees) }\end{array}$ & $\begin{array}{l}\text { Longitude } \\
\text { (degrees) }\end{array}$ & $\begin{array}{c}\text { Length of } \\
\text { ice record } \\
\text { (years) }\end{array}$ & $\begin{array}{c}\text { Bottom } \\
\text { depth } \\
(\mathrm{m})\end{array}$ \\
\hline $\mathrm{E}$ & Ice & $81^{\circ} 18.14^{\prime} \mathrm{S}$ & $148^{\circ} 18.14^{\prime} \mathrm{W}$ & $1908-1995$ & 20.0 \\
$\mathrm{G}$ & Ice/temp & $81^{\circ} 34.25^{\prime} \mathrm{S}$ & $148^{\circ} 35.85^{\prime} \mathrm{W}$ & $1917-1995$ & 20.0 \\
$\mathrm{D}$ & Ice & $81^{\circ} 38.73^{\prime} \mathrm{S}$ & $148^{\circ} 47.16^{\prime} \mathrm{W}$ & $1901-1995$ & 20.0 \\
$\mathrm{C}$ & Ice & $81^{\circ} 39.30^{\prime} \mathrm{S}$ & $148^{\circ} 47.66^{\prime} \mathrm{W}$ & $1836-1995$ & 30.0 \\
$\mathrm{~B}$ & Ice/temp & $81^{\circ} 39.53^{\prime} \mathrm{S}$ & $148^{\circ} 48.72^{\prime} \mathrm{W}$ & $1657-1995$ & 54.0 \\
$\mathrm{H}$ & Ice/temp & $81^{\circ} 44.37^{\prime} \mathrm{S}$ & $148^{\circ} 58.61^{\prime} \mathrm{W}$ & $1898-1995$ & 20.0 \\
$\mathrm{~F}$ & Ice & $81^{\circ} 54.51^{\prime} \mathrm{S}$ & $149^{\circ} 20.22^{\prime} \mathrm{W}$ & $1872-1995$ & 20.0 \\
$\mathrm{~J}$ & Temp & $81^{\circ} 55.50^{\prime} \mathrm{S}$ & $149^{\circ} 22.58^{\prime} \mathrm{W}$ & & \\
\hline
\end{tabular}

tive SAM index years are more likely during strong La Niña years, while Bromwich et al. (1993) found a connection between katabatic surges over inland WA and across the Ross Ice Shelf during El Niño events.

\subsection{Accumulation at Siple Dome}

Satellite microwave observations at Siple Dome first suggested a north to south decrease in accumulation rates (Zwally and Gloersen, 1977). Subsequent studies by Bromwich (1988) concluded that orographic processes controlled the distribution of snow across Siple Dome from storms originating in the Ross and Amundsen seas. Radar stratigraphy was later used to confirm a northward migration of the flow divide (Nereson et al., 1998), and modeling of the radar layer spacing at millennial resolution showed a $70 \%$ decrease in accumulation from north to south across the dome (Nereson et al., 2000). A recent accumulation study derived from the analysis of beta radioactivity in shallow firn cores showed that accumulation is greatest $30 \mathrm{~km} \mathrm{~N}$ of Siple Dome and decreases by half at $30 \mathrm{~km} \mathrm{~S}$, based on net accumulation averages from 1955 to 1997 (Hamilton, 2002).

\subsection{Water isotopes}

To study the effects of ENSO, SAM, and the ASL at Siple Dome, we utilize water isotopes as a climate tracer. The isotopic composition of water molecules is expressed in delta notation $(\delta)$ relative to VSMOW (Vienna Standard Mean Ocean Water) using the following equation:

$\delta_{\text {sample }}=\left[\left(R_{\text {sample }} / R_{\mathrm{VSMOW}}\right)-1\right] \times 1000$,

where $R$ is the isotopic ratio ${ }^{18} \mathrm{O} /{ }^{16} \mathrm{O}$ or $\mathrm{D} / \mathrm{H}$ in the sample or VSMOW. The $\delta \mathrm{D}$ and $\delta^{18} \mathrm{O}$ isotopic composition of precipitation is related to the temperature at which condensation occurs in a cloud (Dansgaard, 1964).

A number of factors are known to affect Antarctic $\delta$ values, including (1) additional poleward evaporation and enrichment of isotopic signals in a parcel of vapor, which limits variability of $\delta$ over the ice sheets (Hendricks et al., 2000; Noone and Simmonds, 2002); (2) katabatic winds that 
transport isotopically depleted inland snow towards the coast (Bromwich et al., 1993); (3) additional kinetic isotopic fractionation during condensation of snow crystals in supersaturated air masses (Jouzel and Merlivat, 1984); (4) changes in temperature and/or location of the primary moisture source region (Kavanaugh and Cuffey, 2003); (5) intermittency and seasonality of precipitation (Jouzel et al., 2007); (6) changes in the strength and/or height of the inversion layer (discussed in Blunier et al., 1998 and Kavanaugh and Cuffey, 2003); and (7) drift of snow accumulation waves at oscillations between $\sim 2.5$ and 100 years (Ekaykin et al., 2002). Isotopes at Siple Dome are assumed to be affected by all of these factors, thus being an integrator of the region's mean climate.

\subsection{This study}

For a typical ice core location, shallow ice cores are used to extract a common climatic signal and determine the amount of climatic variability. Ideally, a deep ice core location will not exhibit large-scale variability over short distances as determined by shallow ice cores. In this study, we analyze a series of seven shallow ice cores $(\mathrm{B}-\mathrm{H})$ spanning a $60 \mathrm{~km}$ north-south transect of Siple Dome. Our measurements of water isotopes, borehole temperatures, and net accumulation rates span the years 1920-1995 for cores C-H, as well as the years 1657-1995 for core B (in the same location as the Siple Dome deep ice core). We use a number of methods to analyze the connection between water isotopes, net accumulation, and climate oscillations like ENSO and SAM, including time-series analysis, principal component analysis, and cross-wavelet transform. Our study shows that Siple Dome exhibits significant climate variability over the $60 \mathrm{~km}$ transect, and that a common climate signal cannot be extracted from the shallow ice cores for the time period in question (1920-1995). These results lead to important considerations for the interpretation of ice core records on coastal dome locations in West Antarctica.

\section{Methods}

\subsection{Field and laboratory}

Siple Dome shallow cores B-H were drilled in the 19961997 field season to explore the spatial variability of various climatic and meteorological signals. Following extraction, these cores were analyzed for stable hydrogen and oxygen isotopes of water (Steig and White, 2003). The ice was sampled at the National Ice Core Laboratory (NICL) in Lakewood, Colorado, and isotopically analyzed at the Institute of Arctic and Alpine Research (INSTAAR) Stable Isotope Lab (SIL) at the University of Colorado.

The SIL analyzed both $\delta \mathrm{D}$ and $\delta^{18} \mathrm{O}$ values of water using SIRA Prism Micromass mass spectrometers. Hydrogen isotopic ratios were determined using an automated direct injection uranium reduction system (Vaughn et al., 1998) with an uncertainty of $\pm 1.0 \%$. Oxygen isotopic ratios were determined with an automated version of the traditional $\mathrm{CO}_{2} / \mathrm{H}_{2} \mathrm{O}$ equilibration method (Epstein and Mayeda, 1953) with an uncertainty of $\pm 0.1 \%$. The shallow ice cores were sampled at $5 \mathrm{~cm}$ increments, yielding subannual temporal resolution (approximately 2-6 samples per year) until the year 1920. High-temporal-resolution data for core B extends as far back as 1657 .

A depth-age dating scheme for the Siple Dome shallow ice cores was developed by Alley (2003). The dating of the ice cores was performed using visual stratigraphy on a light table over fluorescent tubes (after the core had been sectioned longitudinally). Indicators were used to determine how obvious dating choices were: 3 is clear indication, 2 is fair indication, and 1 is poor indication. Even when the choice of a depth-age was not obvious, stratigraphy was "forced" towards an expected value. For the age interval 1920-1995 (from 0 to $\sim 17 \mathrm{~m}$ ), cores B, C, D, E, F, G, and $\mathrm{H}$ had 16 poor indications, 24 poor indications, 7 poor indications, 23 poor indications, 9 poor indications, 14 poor indications, and 9 poor indications, respectively. For core B at depths of 23 $100 \mathrm{~m}$, two independent estimates of annual layer counting were conducted. Control group one counted 75 years while control group two counted 71 years, resulting in a difference of about $5 \%$. Alley (2003) suggests that absolute accuracy is $10 \%$ or better for all shallow ice cores, meaning that from 1920 to 1995 the absolute dating may be off by about 4 years, or on average one wrong pick every $\sim 19$ years.

In this study, we employ a number of field and laboratory measurements for interpretation of the isotopic and net accumulation records. Twenty-meter borehole temperatures taken by Clow (1996) constrain the mean annual temperature and local climate at Siple Dome. The borehole measurements were taken at a depth not influenced by seasonal fluctuations in surface temperature with an uncertainty of $\pm 0.003{ }^{\circ} \mathrm{C}$. Borehole temperature data is not available for core $\mathrm{E}$ on the north flank (Pacific facing) and core $\mathrm{F}$ on the south flank (inland facing), so we estimate these values using the other known borehole temperatures and the local at-

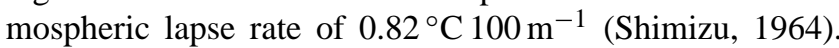
Net accumulation rates were determined from the volume of snow per year in the ice core, based on the depth-age dating scheme by Alley (2003), and a third-order polynomial fit of $1 \mathrm{~m}$ density measurements taken by Lamorey (2003). The polynomial fit introduces less than a $0.1 \%$ error to the known $1 \mathrm{~m}$ density measurements, while the densities in between are interpolated. The uncertainty of net accumulation is then dependent on the depth-age dating scheme. The standard errors of the net accumulation mean for cores E, G, D, C, B, $\mathrm{H}$, and $\mathrm{F}$ are $0.2,0.2,0.3,0.2,0.2,0.2$, and $0.2 \mathrm{~cm}$ year $^{-1}$ ice eq. (ice equivalent), respectively. All local climate information, including elevation, borehole temperatures, net accumulation, and water isotopes, is shown in Table 2. 
Table 2. Siple Dome shallow ice core data summary. The $\delta \mathrm{D}, \delta \mathrm{D}$ standard deviation, net accumulation, and net accumulation standard deviation (SD) values pertain to the time period 1920-1995.

\begin{tabular}{llcccccc}
\hline Site & $\begin{array}{l}\text { Location } \\
(\mathrm{km})\end{array}$ & $\begin{array}{c}\text { Elevation } \\
(\mathrm{m} \text { a.s.1. })\end{array}$ & $\begin{array}{c}\text { Borehole } \\
\text { temp. }\left({ }^{\circ} \mathrm{C} \text { at }\right. \\
20 \mathrm{~m} \text { depth })\end{array}$ & $\begin{array}{c}\delta \mathrm{D} \\
(\%)\end{array}$ & $\begin{array}{r}\delta \mathrm{D} \mathrm{SD} \\
(\%)\end{array}$ & $\begin{array}{c}\text { Net accumulation } \\
\left(\mathrm{cm} \mathrm{year}^{-1} \text { ice eq. }\right)\end{array}$ & $\begin{array}{c}\text { Net accumulation } \\
\text { SD } \\
\left(\mathrm{cm} \mathrm{year}^{-1} \text { ice eq. }\right)\end{array}$ \\
\hline $\mathrm{E}$ & $30^{\circ} \mathrm{N}$ & 400 & & -199.1 & 16.0 & 11.7 & 3.6 \\
$\mathrm{G}$ & $10^{\circ} \mathrm{N}$ & 590 & -24.79 & -202.4 & 14.8 & 13.4 & 4.2 \\
$\mathrm{D}$ & $1^{\circ} \mathrm{N}$ & 615 & & -205.4 & 13.9 & 11.0 & 3.4 \\
$\mathrm{C}$ & 0 & 615 & & -203.0 & 14.1 & 11.2 & 3.1 \\
$\mathrm{~B}$ & $0.5^{\circ} \mathrm{S}$ & 615 & -25.12 & -202.3 & 13.9 & 11.1 & 2.9 \\
$\mathrm{H}$ & $10^{\circ} \mathrm{S}$ & 590 & -25.33 & -207.5 & 13.8 & 9.3 & 3.1 \\
$\mathrm{~F}$ & $30^{\circ} \mathrm{S}$ & 450 & & -220.2 & 11.2 & 8.2 & \\
$\mathrm{~J}$ & $32^{\circ} \mathrm{S}$ & 435 & -24.22 & & & & \\
\hline
\end{tabular}

\subsection{Data and procedures}

We compare $\delta$ D to the Niño 3.4 index (Niño 34), the Southern Annular Mode index (SAM index), and the ASL actual central pressure index (ASL index). Niño 34 is a proxy for sea surface temperatures (SST) in the region of the tropical Pacific bounded at $120-170^{\circ} \mathrm{W}, 5^{\circ} \mathrm{S}-5^{\circ} \mathrm{N}$ (Trenberth and Hoar, 1997). Niño 34 provides a reliable record of ENSO dating back to 1950 . The SAM index is defined as the leading principal component of $850 \mathrm{hPa}$ geopotential height anomalies poleward of $20^{\circ} \mathrm{S}$ (Thompson and Wallace, 2000), providing a short record of opposing pressure anomalies centered in the Antarctic near $40-50^{\circ} \mathrm{S}$. The SAM index provides a reliable record dating back to 1979 and is a leading mode of climate variability in the high southern latitudes. The ASL index describes the monthly and seasonal variability of the ASL relative central pressure and location reconstructed from ERA-Interim reanalyses dating back to 1979 (Hosking et al., 2013). The ASL index is strongly correlated $(p<0.01)$ to the SAM for all seasons. Due to the strong correlation, we choose to use the SAM index (rather than the ASL index) throughout the rest of this paper for comparison to Siple Dome shallow ice cores.

Frequency analysis of the water isotope records was performed using a cross-wavelet (XWT) coherence Matlab package (Grinsted et al., 2004; Torrence and Compo, 1998). The XWT changes one-dimensional time series into timefrequency space, creating a two-dimensional image of crossmodal variability and phase lag through time. The wavelet power is based on a red noise background spectrum. In our analysis, we place emphasis on the $\delta \mathrm{D}$ of core $\mathrm{B}\left(\delta \mathrm{D}_{\mathrm{B}}\right)$, the longest shallow ice core (dating to 1657), which was drilled in the same location as the deep Siple Dome ice core.

\section{Results and discussion}

\subsection{Net accumulation}

Previous modeling at 1000-10000-year timescales shows asymmetry in Siple Dome north-south accumulation existed for many thousands of years into the past (Nereson et al., 2000). Our study confirms these findings at smaller and more recent timescales, and we find agreement with other near-term accumulation studies on Siple Dome. Table 3 shows a comparison of net accumulation rates from 1955 to 1995 found by Hamilton (2002) in comparison to this study. Hamilton (2002) used detection of elevated levels of gross beta radioactivity at the 1955 bomb testing reference horizon to infer averaged accumulation rates, whereas we use an estimation of net accumulation based on depthage dating and density profiles. Uncertainty of net accumulation measurements in the Hamilton (2002) study was determined using density profiles from snow pits and submergence velocity, or the "coffee-can" technique. This method entails repeat GPS surveys over a 3-year period of markers installed at 5-20 $\mathrm{m}$ depth in the firn, which are used to quantify measurement repeatability and the steadiness of firn densification and accumulation rate. Hamilton (2002) assigned a maximum uncertainty on net accumulation measurements of about $1.4 \mathrm{~cm}_{\text {year }}{ }^{-1}$ ice eq. In this study, the standard error of the net accumulation mean (1955-1995) for each ice core varies between 0.3 and $0.4 \mathrm{~cm}_{\text {year }}{ }^{-1}$ ice eq., and the overall uncertainty would depend on the accuracy of the depth-age scale, the accuracy of $1 \mathrm{~m}$ density measurements, and alteration of the original signal due to postdepositional processes (discussed by Fisher et al., 1985 and Frezzotti et al., 2007).

Hamilton (2002) accumulation values differ with this study by about $\sim 25 \%$ at $30 \mathrm{~km} \mathrm{~N}$ and $20 \%$ at $10 \mathrm{~km} \mathrm{~S}$, whereas the other locations differ by $4 \%$ or less. The net accumulation values may differ due to differences in geographic measurement locations, uncertainty in the depth-age dating scheme used in this study, postdepositional processes, or varying methodologies for calculating the density profile. 


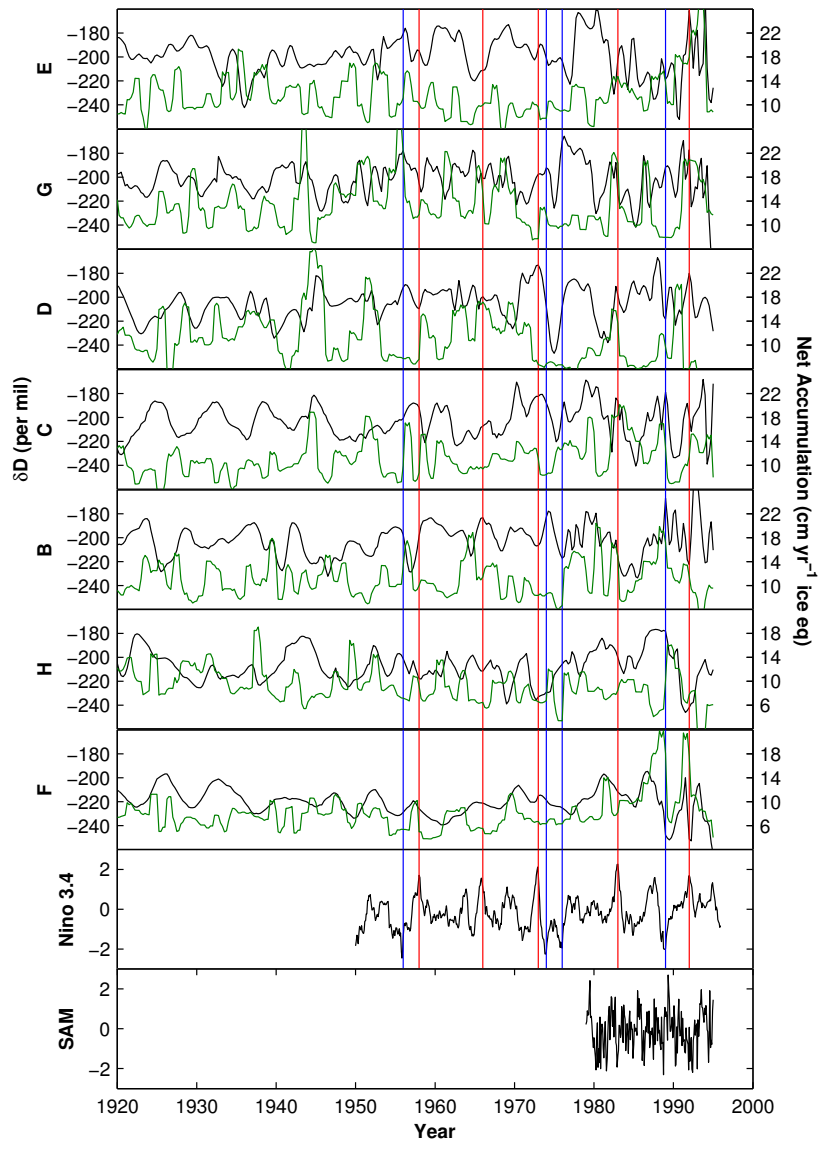

Figure 2. Siple Dome shallow ice core $\delta \mathrm{D}$ (black lines) and net accumulation records (green lines). The Niño 3.4 and SAM indexes are also shown. Strong El Niño years (red lines) and strong La Niña years (blue lines) are defined as 5 consecutive months greater than or less than $1.5^{\circ} \mathrm{C}$ sea surface temperature anomalies for the Niño 3.4 region, respectively.

In this study, we find that the standard deviation of net accumulation between 1955 and 1995 for each ice core site varies between 2.7 and $4.5 \mathrm{~cm}$ year ${ }^{-1}$ ice eq. (Table 3 ). The highest net accumulation value occurs at $10 \mathrm{~km} \mathrm{~N}$, suggesting that increased Pacific flank accumulation rates (and northward migration of the dome) persisted towards the present at subcentennial timescales. It is not clear why net accumulation is greatest at $10 \mathrm{~km} \mathrm{~N}$ (core G) and not $30 \mathrm{~km} \mathrm{~N}$ (core E). One possibility is that the area around core $\mathrm{E}$ is not cold enough to allow local condensation, which instead occurs further inland, at higher elevations. A second possibility is that an inversion layer forms during certain parts of the year at Siple Dome, which tends to cap air masses, and eventual precipitation, at elevations above core E. A final possibility is that surface winds move snow after deposition, producing uneven loading due to dome topography. The time series of net accumulation and water isotopes are shown in Fig. 2.
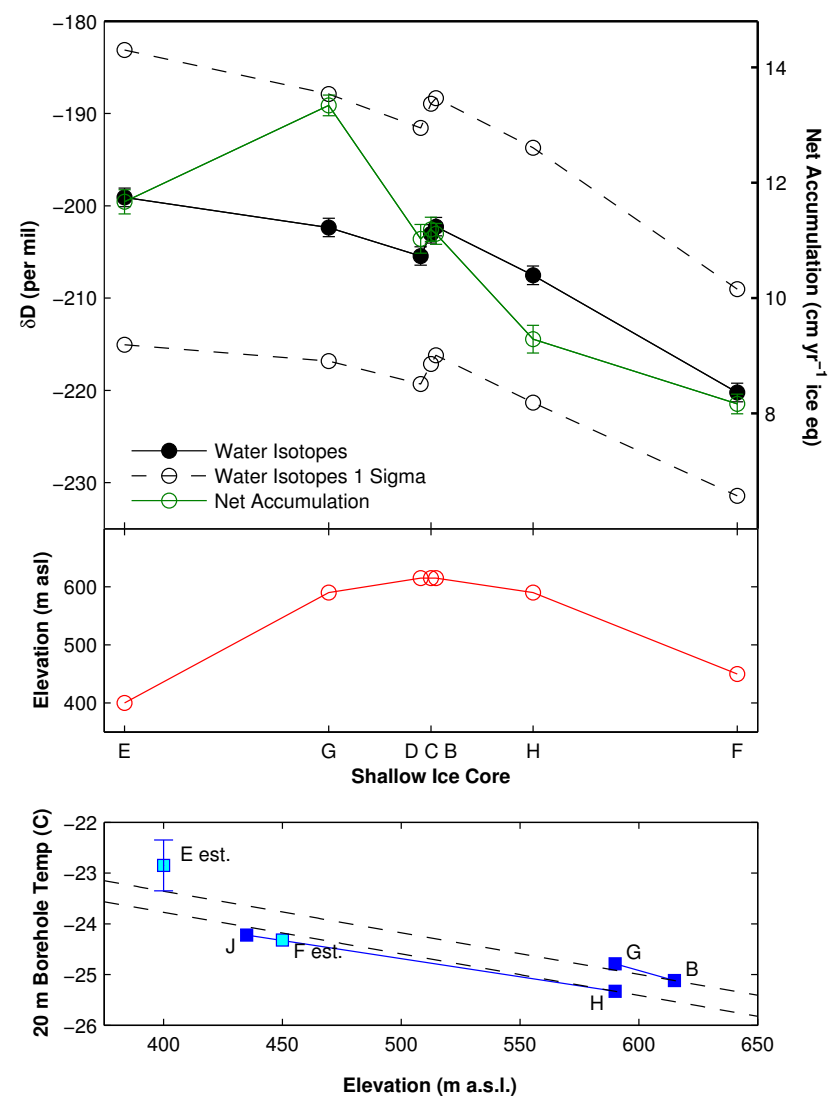

Figure 3. Top panel: shallow ice core mean $\delta \mathrm{D}$ (solid black line, uncertainty bars attached), $\delta \mathrm{D}$ standard deviation (black dashed line), and mean net accumulation (solid green line, standard error bars attached) on Siple Dome from 1920 to 1995. Middle panel: the elevation profile of shallow ice cores at Siple Dome. Bottom panel: shallow $20 \mathrm{~m}$ borehole temperatures recorded at Siple Dome. Dark blue squares denote temperature measurements. Blue lines designate temperature trends. Dashed black lines designate adiabats $\left(0.82{ }^{\circ} \mathrm{C} 100 \mathrm{~m}^{-1}\right)$. No borehole temperature was taken in the vicinity of core $\mathrm{E}$ ( $30 \mathrm{~km}$ north) or core $\mathrm{F}$ ( $30 \mathrm{~km}$ south). These temperature values (light blue squares) are estimated using adiabats and temperature trends.

\subsection{Borehole temperatures}

Shallow $20 \mathrm{~m}$ borehole temperature observations (uncertainty of $\pm 0.003^{\circ} \mathrm{C}$ ) reveal two distinct temperature gradients across Siple Dome, including a cold regime on the inland flank and a warmer regime on the dome summit and Pacific flank (Fig. 3). The borehole temperature at core $\mathrm{G}$ $(10 \mathrm{~km} \mathrm{~N})$ relative to core $\mathrm{B}(0.5 \mathrm{~km} \mathrm{~S})$ falls within $0.13^{\circ} \mathrm{C}$ from that expected by the local atmospheric lapse rate of $0.82{ }^{\circ} \mathrm{C} 100 \mathrm{~m}^{-1}$ (Shimizu, 1964). The borehole temperature at core $\mathrm{J}(32 \mathrm{~km} \mathrm{~S})$ relative to core $\mathrm{H}(10 \mathrm{~km} \mathrm{~S})$ is colder by $0.05^{\circ} \mathrm{C}$ than would be predicted by the local adiabat.

We estimate borehole temperature values at core $\mathrm{E}$ and core $\mathrm{F}$ relative to the local atmospheric lapse rate and the 
Table 3. Comparison of Siple Dome net accumulation rate studies from 1955 to 1995 , expressed as water equivalents. The standard deviation of net accumulation is also shown for this study. The Hamilton (2002) study standard deviation is not available because the data is not a time series, but rather a long-term average based on the 1955 bomb testing reference horizon.

\begin{tabular}{lrrc}
\hline $\begin{array}{l}\text { Site } \\
\text { (distance } \\
\text { from the } \\
\text { divide) }\end{array}$ & $\begin{array}{r}\text { Hamilton (2002) } \\
\left.\text { (cm year }^{-1} \text { ice eq. }\right)\end{array}$ & $\begin{array}{r}\text { This Study } \\
\left(\mathrm{cm} \mathrm{year}^{-1} \text { ice eq. }\right)\end{array}$ & $\begin{array}{c}\text { This Study } \\
\text { standard deviation }^{\left(\mathrm{cm}_{\text {year }}-1\right.} \text { ice eq. }\end{array}$ \\
\hline $30 \mathrm{~km} \mathrm{~N}$ & & & \\
$10 \mathrm{~km} \mathrm{~N}$ & 15.5 & 11.7 & 4.0 \\
$0 \mathrm{~km}$ & 14.0 & 13.4 & 4.5 \\
$10 \mathrm{~km} \mathrm{~S}$ & 12.1 & 11.2 & 3.1 \\
$30 \mathrm{~km} \mathrm{~S}$ & 10.4 & 9.3 & 2.7 \\
\hline
\end{tabular}

borehole temperature measurement trends between sites $\mathrm{G}-\mathrm{L}$ and $\mathrm{J}-\mathrm{H}$, respectively. For core $\mathrm{E}(30 \mathrm{~km} \mathrm{~N}, 400 \mathrm{~m}$ a.s.l.), we estimate a temperature range from -23.23 to $-22.28^{\circ} \mathrm{C}$. For core F ( $450 \mathrm{~m}$ a.s.l.), we estimate a value of $-24.32^{\circ} \mathrm{C}$. We find a temperature difference between $30 \mathrm{~km} \mathrm{~N}$ and $30 \mathrm{~km} \mathrm{~S}$ of about $1.09-2.04{ }^{\circ} \mathrm{C}$. If the temperature trend on the inland flank is extrapolated to $400 \mathrm{~m}$ a.s.l. using the atmospheric lapse rate, the difference in temperature at $400 \mathrm{~m}$ a.s.l. between the Pacific and inland flanks would be about $0.7-$ $1.6^{\circ} \mathrm{C}$. The difference in temperatures suggests variable forcing mechanisms acting on either side of the dome that could influence the water isotope and net accumulation records. We discuss this concept later in the paper.

\subsection{Water isotopes}

If we assume that near-surface temperature is controlling water isotopes at Siple Dome, then we would expect a linear $\delta$-temperature $(\delta-T)$ relationship. This is not the case. We test the $\delta-T$ relation by using an Antarctic correlation of $6.34 \%$ o $0.09 \%$ oper $1{ }^{\circ} \mathrm{C}$ (Masson-Delmotte et al., 2008). There is not enough information to construct a local $\delta-T$ spatial slope at Siple Dome, but for this study an estimate of the slope will suffice.

The temperature difference range between core $\mathrm{B}$ (dome) and core $\mathrm{E}$ (Pacific) is estimated to be $1.89-2.84^{\circ} \mathrm{C}$, which corresponds to $\delta \mathrm{D}$ expected isotope depletions on the dome summit of about $12.0-18.0 \%$, respectively. However, the actual difference between $\delta \mathrm{D}_{\mathrm{B}}$ and $\delta \mathrm{D}_{\mathrm{E}}$ is only $3.2 \%$ (Fig. 3), meaning that the water isotopes are too heavy on the dome summit in relation to elevation-based temperature estimates at core $\mathrm{E}$. The $\delta-T$ discontinuity is more pronounced on the inland flank. The borehole temperature estimate at core F (inland) is warmer than core B (dome), suggesting that water isotopes should be heavier at core F (inland). In fact, the isotopes are significantly depleted compared to core B by $-17.9 \%$ (Fig. 3). These discrepancies show that a linear $\delta-$ $T$ relation is too simplistic to explain climate at Siple Dome over the time period 1920-1995.

\section{4 $\delta \mathrm{D}$ standard deviation}

Siple Dome shallow ice cores show a relatively linear decrease in $\delta \mathrm{D}$ standard deviation from north to south. At $30 \mathrm{~km} \mathrm{~N}$, the water isotope signal is amplified with a standard deviation of $16.0 \%$, whereas at $30 \mathrm{~km} \mathrm{~S}$ the water isotope signal is dampened with a standard deviation of $11.9 \%$. The loss of signal moving southward across the dome can be related to a number of contributing factors, including (1) erosion of the original summer-winter water isotope signal due to diffusion in the firn (Cuffey and Steig, 1998). For example, shallow ice core sites with low accumulation (i.e., core F, inland) would have more pronounced diffusion and a smaller standard deviation than an ice core site with high accumulation (i.e., core E, Pacific). (2) Interannual variations in climate that can be more or less pronounced over a certain time period and which may have different effects on each shallow ice core site. For example, the Pacific flank and dome summit may experience more storm systems on average taking a direct path from the Ross and Amundsen seas (i.e., less snow events leading to an amplified $\delta \mathrm{D}$ signal and high standard deviations), while the inland flank could experience more storm systems on average that follow an indirect cross-continental route (i.e., more snow events leading to a dampened $\delta \mathrm{D}$ signal and low standard deviations). (3) Intermittency of precipitation at a given shallow ice core site relative to other sites, such as the seasonality of precipitation discussed by Jouzel et al. (2007). (4) Variations in net accumulation and water isotopes related to postdepositional processes. For example, the dampened inland water isotope signal at core F may be related to katabatic winds traveling from inland WA towards the coast (Bromwich et al., 1993). The cold katabatic winds would tend to sink and flow along the valleys towards the coast, bringing isotopically lighter wind-blown snow with low $\delta \mathrm{D}$ standard deviation from higher elevations in the interior of Antarctica.

\subsection{Principal component analysis}

Principal component analysis (PCA) was performed using all seven shallow ice core $\delta \mathrm{D}$ records (Fig. 4). The first five components of the PCA explain 22, 17, 16, 14, and $13 \%$ of the total $\delta \mathrm{D}$ variance. This suggests that multiple processes control the stable isotopes of snow, and importantly that no single process dominates. The biplot of component 1 vs. component 2 shows vector representations of the coefficients of the $\delta \mathrm{D}$ records on the first two principal components. For component 1 on the vertical axis, core $\mathrm{F}$ and core $\mathrm{H}$ (inland) have negative coefficients, whereas cores E, G, D, C, and B (Pacific and summit) have positive coefficients. Component 1 shows a fundamental difference in Pacific and summit $\delta \mathrm{D}$ records versus inland $\delta \mathrm{D}$ records, an occurrence that we also see in borehole temperature measurements and discrepancies in water isotopes. For component 2 on the horizontal axis, core $\mathrm{B}$ and core $\mathrm{E}$ have negative coefficients, and cores $\mathrm{G}$, 
Table 4. Siple Dome correlation matrix for shallow ice core water isotope $\delta \mathrm{D}$ time series (bottom left of matrix) and net accumulation (top right of matrix). Values with a star indicate significant Pearson's correlation values of less than 0.05 . Only similar time series should be interpreted from the table (i.e. accum with accum and iso with iso, but not accum with iso).

\begin{tabular}{lllllllll}
\hline- & E accum & G accum & D accum & C accum & B accum & H accum & F accum & - \\
\hline E iso & - & 0.04 & -0.09 & 0.08 & -0.02 & -0.02 & $0.26^{*}$ & E accum \\
G iso & $0.13^{*}$ & - & 0.06 & 0.06 & $-0.12^{*}$ & $-0.17^{*}$ & -0.03 & G accum \\
D iso & 0.02 & $0.13^{*}$ & - & 0.04 & -0.01 & $0.13^{*}$ & $-0.08^{*}$ & D accum \\
C iso & $0.20^{*}$ & 0.05 & 0.09 & - & -0.05 & $-0.18^{*}$ & $0.19^{*}$ & C accum \\
B iso & 0.09 & 0.04 & -0.11 & 0.09 & - & -0.05 & $0.19^{*}$ & B accum \\
H iso & $-0.20^{*}$ & -0.02 & -0.09 & 0.05 & -0.03 & - & -0.15 & $\mathrm{H}$ accum \\
F iso & -0.05 & 0.08 & $-0.13^{*}$ & $0.18^{*}$ & $-0.22^{*}$ & $0.19^{*}$ & - & F accum \\
\hline- & E iso & G iso & D iso & C iso & B iso & H iso & F iso & - \\
\hline
\end{tabular}
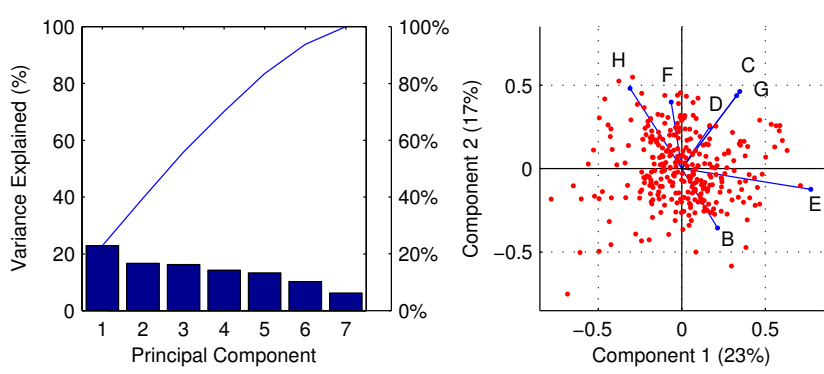

Figure 4. Left panel: principal component analysis of the Siple Dome shallow ice core $\delta \mathrm{D}$ records. Right panel: biplot of component 1 vs. component 2.

$\mathrm{C}, \mathrm{D}, \mathrm{H}$, and $\mathrm{F}$ have positive coefficients. It is unclear why core $\mathrm{B}$ and core $\mathrm{E}$ would be unique in component 2. Perhaps the differences arise during postdepositional processes resulting from oscillations in snow waves on the surface of the ice sheet (Ekaykin et al., 2002) or by some other unknown forcing.

Some correlation exists between certain principal components and the Niño 34 and SAM indexes (Fig. 5). The SAM index and PC3 are significantly correlated $(p$ value $<0.05$ ) with an $r$ value of 0.25 . The Niño 34 index and PC5 are significantly correlated ( $p$ value $<0.05$ ) with an $r$ value of 0.19 . These results suggest ENSO and SAM have a role in the water isotope signal at Siple Dome, but PC1, PC2, and PC4 exhibit additional complexity that is not readily explained.

\subsection{Time-series analysis}

We compare time-series records of net accumulation and water isotopes using correlation matrices (Table 4). We find that none of the net accumulation or water isotope time series correlate amongst themselves. For example, core $\mathrm{C}(0 \mathrm{~km})$ and core $\mathrm{B}(0.5 \mathrm{~km} \mathrm{~S})$ are only separated by $0.5 \mathrm{~km}$, yet the correlation values for $\mathrm{C}$ vs. $\mathrm{B}$ net accumulation and $\mathrm{C}$ vs. $\mathrm{B}$ water isotopes are -0.05 and 0.09 , respectively. The Pearson values for these correlations are insignificant $(p>0.05)$.

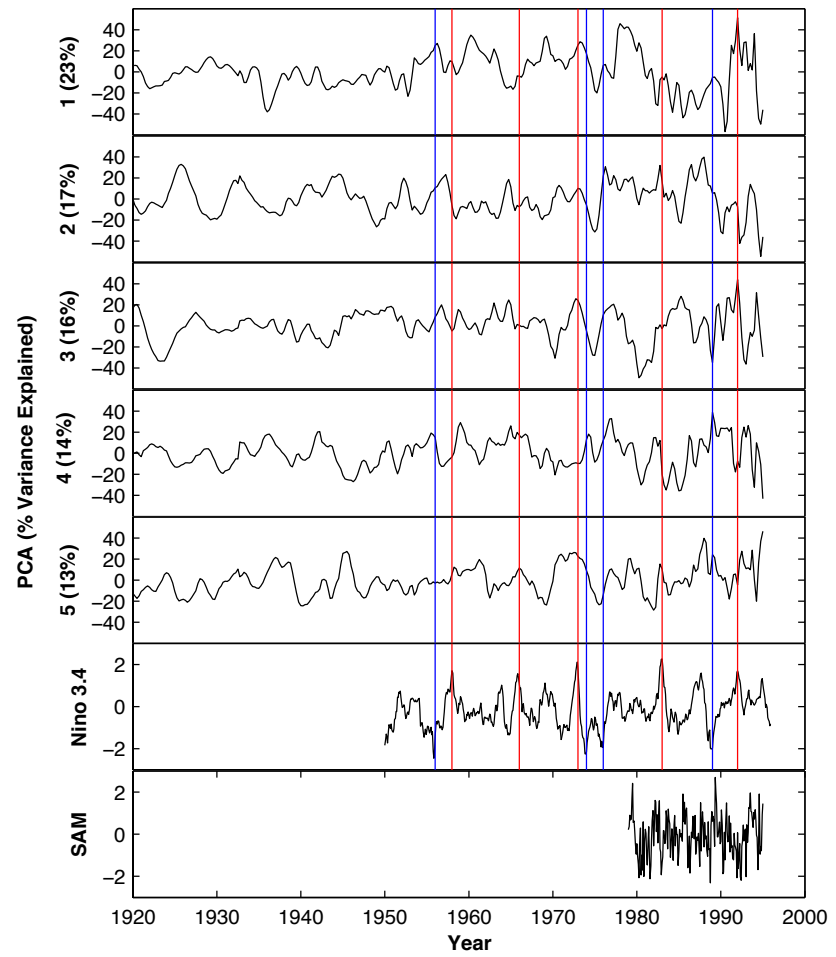

Figure 5. The first 5 principal components of the shallow ice core $\delta \mathrm{D}$ records are compared with the Niño 3.4 and SAM indexes. Strong El Niño years (red lines) and strong La Niña years (blue lines) are defined as 5 consecutive months greater than or less than $1.5^{\circ} \mathrm{C}$ sea surface temperature anomalies for the Niño 3.4 region, respectively.

The most correlated net accumulation time series (significant $p$ value $<0.05)$ are core $\mathrm{E}(30 \mathrm{~km} \mathrm{~N})$ and core $\mathrm{F}(30 \mathrm{~km} \mathrm{~S})$ with an $r$ value of 0.26 . The most correlated water isotope time series (significant $p$ value $<0.05)$ are core $\mathrm{E}(30 \mathrm{~km} \mathrm{~N})$ and core $\mathrm{C}(0 \mathrm{~km})$ with an $r$ value of 0.20 . Neither correlation implies causation. 
Table 5. Siple Dome correlation values for both water isotope $\delta \mathrm{D}$ and net accumulation versus either Niño 34 or SAM. Values with a star indicate significant Pearson's correlation values of less than 0.05 .

\begin{tabular}{llllllll}
\hline- & E iso & G iso & D iso & C iso & B iso & H iso & F iso \\
\hline Niño 34 & -0.12 & -0.1 & 0.08 & 0.12 & 0.01 & -0.13 & 0.11 \\
SAM & -0.05 & 0.09 & 0.17 & 0.01 & $-0.28^{*}$ & -0.04 & -0.16 \\
\hline- & E accum & G accum & D accum & C accum & B accum & H accum & F accum \\
\hline Niño 34 & $0.19^{*}$ & 0.08 & 0.08 & 0.06 & 0.08 & -0.05 & $0.17^{*}$ \\
SAM & -0.07 & -0.03 & -0.16 & 0.17 & $-0.27^{*}$ & 0.04 & -0.24 \\
\hline
\end{tabular}

It is counterintuitive that shallow ice cores so closely separated would have such differing net accumulation and water isotope histories. Assuming precipitation rates are the same at the time of deposition between sites $\mathrm{C}$ and B, postdepositional processes (i.e., snow waves or wind loading) may be altering the net accumulation signal. If net accumulation is in fact changed by postdepositional processes, then a similar outcome would be expected for the water isotope records, which we observe. To achieve a coherent record amongst the shallow ice cores, the water isotope signals would have to be smoothed, which would reduce or eliminate yearly, biyearly, decadal, and subcentennial oscillations.

We also compare time-series records of net accumulation and water isotopes to the Niño 34 and SAM indexes (Fig. 2). We define strong El Niño years (red lines) and strong La Niña years (blue lines) as 5 consecutive months greater than or less than $1.5^{\circ} \mathrm{C}$ sea surface temperature anomalies for the Niño 3.4 region, respectively. We find that both water isotope and net accumulation shallow ice core records do not share a common signature with any of the strong ENSO events. Individual time-series correlation values for both water isotopes and net accumulation versus either Niño 34 or SAM vary between about -0.30 and 0.30 (Table 5). Most time-series correlations are insignificant $(p>0.05)$. Some portions of the time series go into and out of phase with the Niño 34 or SAM indexes, so correlation is higher for certain parts of the record and lower for others.

\subsection{Cross-wavelet transform}

Since the PCA components relate to the entire array of seven shallow ice cores, we perform cross-spectral wavelet analysis (XWT) on a single ice core location. The XWT of the $\delta \mathrm{D}_{\mathrm{B}}$ record versus net accumulation, Niño 34, and SAM is shown in Fig. 6. The $\delta \mathrm{D}_{\mathrm{B}}$ and core $\mathrm{B}$ net accumulation XWT from 1657 to 1995 has strong, significant, and noncontinuous power in oscillations at $2-5$ years and strong, nonsignificant, continuous power in oscillations between 16 and 32 years. The $\delta \mathrm{D}_{\mathrm{B}}$ and Niño 34 XWT from 1950 to 1995 shows strong, significant, and continuous power in oscillations ranging from 2 to 7 years. The $\delta \mathrm{D}_{\mathrm{B}}$ and SAM XWT from 1979 to 1995 shows strong, significant, and continuous power in oscillations at $1-3$ years from about 1988 to
1995. All shallow ice core XWT results can be found in Appendix A and show similar results.

The fact that core B XWT exhibits ENSO-type frequencies is not surprising since ENSO oscillations can be found in many of the world's time series. In short, ENSO is intrinsically a part of global climate. We note that while the XWT analysis for $\delta \mathrm{D}_{\mathrm{B}}$ versus net accumulation, Niño 34, and SAM finds common power at varying periodicities, the oscillations go into and out of phase throughout the entire record (as interpreted in the phase arrows). In other words, common oscillations at high power are not phase locked, and cannot be interpreted as a link between any of the time series. The XWT plots show that while ENSO and SAM likely affect climate at Siple Dome, the Siple Dome water isotope record is not a useful ENSO or SAM proxy on the first order.

\subsection{Climate signal}

We find that the climatology of Siple Dome expressed in water isotopes, net accumulation, and borehole temperatures is highly complex. Although one of the original goals of the West Antarctic Ice Sheet initiative was to reconstruct regional climate oscillation signals such as ENSO, we can find no direct transect-wide relation amongst the water isotope or net accumulation time series with strong El Niño, strong La Niña, or SAM events. However, we do find significant correlations between the SAM index and PC3 ( $r$ value of 0.25 ) and between the Niño 34 index and PC5 ( $r$ value of 0.19 ). The XWT analysis also shows that shallow ice cores share a common power with ENSO and SAM, but are not phaselocked. This suggests that both ENSO and SAM are superimposed on a water isotope signal that is affected by many other climatic forcings.

Orographic uplift alone does not control isotope values at Siple Dome because shallow ice core $\delta \mathrm{D}$ values do not conform with elevation and borehole temperatures. As component 1 of the PCA and borehole temperatures suggest, there may be fundamental differences in climate on the Pacific and inland flanks. The exact nature of these mechanisms is unknown. Perhaps the inland flank is more influenced by katabatic winds originating from the interior of WA, while the Pacific flank is more influenced by weather systems originating in the Amundsen and Ross seas. Differences in 

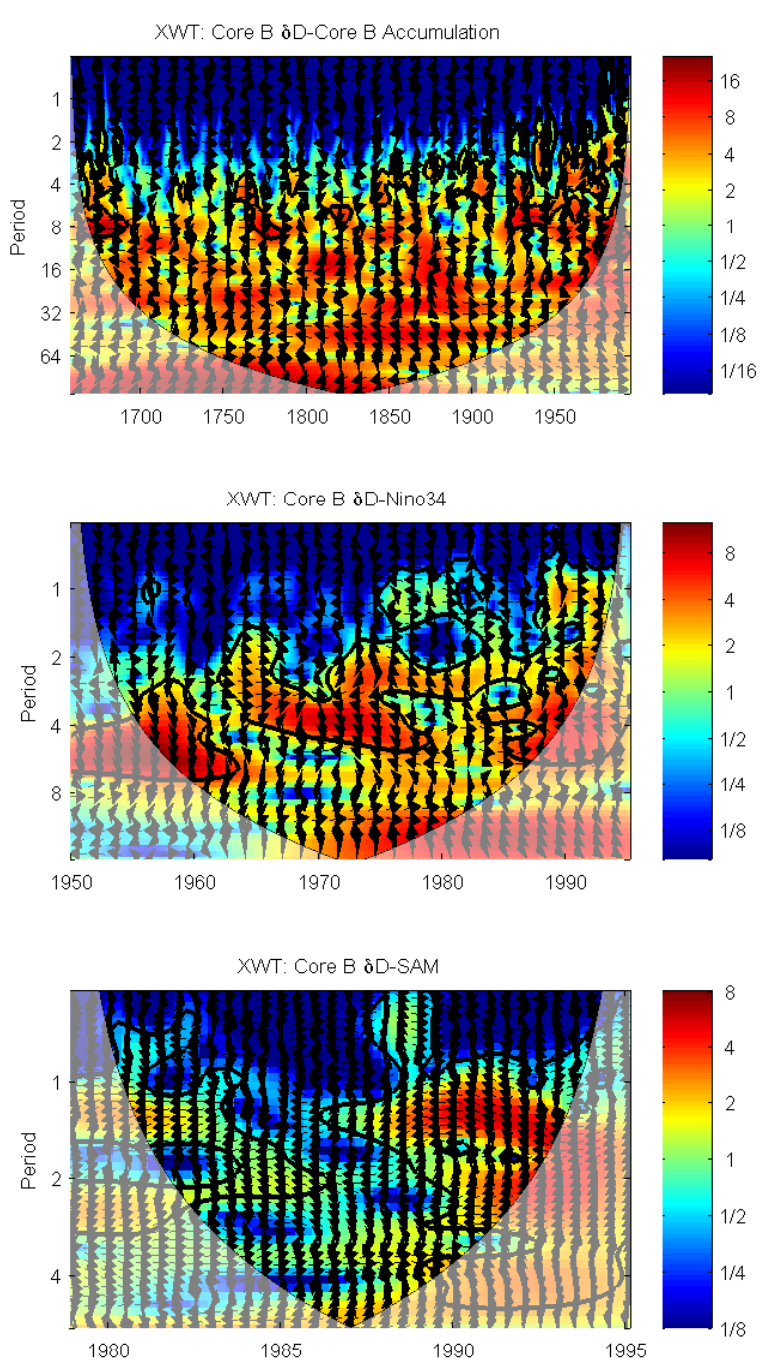

Figure 6. XWT plot of regions in time-frequency space where the time series in question show high common power. The phase arrows show the relative phasing of the time series (right: in-phase, left: anti-phase, down: $X$ leading $Y$ by $90^{\circ}$, up: $Y$ leading $X$ by $90^{\circ}$ ). Top panel: core $\mathrm{B} \delta \mathrm{D}$ and core $\mathrm{B}$ net accumulation XWT from 1657 to 1995. Middle panel: core B $\delta$ D and Niño 3.4 XWT from 1950 to 1995. Bottom panel: core B $\delta$ D and SAM XWT from 1979 to 1995. All shallow ice core XWT plots can be found in Appendix A.

postdepositional processes (snow waves and/or wind scouring) may also play a role.

In a study of net accumulation signals at Talos Dome, Frezzotti et al. (2007) found that spatial variability at the kilometer scale is one order of magnitude higher than temporal variability at the multidecadal/century scale for ice core sites with net accumulation of less than $20 \mathrm{~cm}_{\text {year }}{ }^{-1}$ ice eq. All shallow ice core sites at Siple Dome fall within this range. We find that significant variations in net accumulation and water isotopes occur at distances as close as $0.5 \mathrm{~km}$, which as Frezzotti et al. (2007) shows, may be more influenced by subkilometer ice sheet morphology than a true climate signal.
This suggests that high-frequency oscillations (multiyear) in the net accumulation and water isotope time series cannot be interpreted solely as a local or regional climate signal. Frezzotti et al. (2007) also shows that accumulation hiatuses can occur at sites with net accumulation lower than $12 \mathrm{~cm}_{\text {year }}{ }^{-1}$ ice eq. This finding pertains to all shallow ice core sites at Siple Dome except core G. Gaps in accumulation could cause misidentification of annual layers in ice core dating, as well as inaccuracies in statistical analysis of ice core time-series records. This should be considered when interpreting deep ice cores in locations with low net accumulation or marked variations in shallow ice core signals over small distances.

\section{Conclusions}

Analysis of seven shallow ice cores spanning a relatively flat $60 \mathrm{~km}$ north-south transect of Siple Dome have been analyzed for borehole temperatures, net accumulation, and water isotopes. Multiple statistical analysis methods reveal a complex micro climate. We find that Siple Dome has two distinct temperature profiles, including a warmer temperature regime on the Pacific flank and dome summit, and a colder temperature regime on the inland flank. Water isotope values do not conform directly to temperature measurements, nor do any of the water isotope and net accumulation times series show strong agreement amongst themselves or to extrapolar climate forcings like the El Niño-Southern Oscillation and the Southern Annular Mode. We find indications that postdepositional snow movements may convolute both water isotope and net accumulation time series.

Due to the complexity of climate in the region, our findings suggest caution in interpreting high-frequency water isotope and net accumulation signals in the coastal dome locations of West Antarctica. Ongoing research at the WAIS Divide (an inland ice core site) and Roosevelt Island (a coastal ice core site on an island in the Ross Sea) may give better indications whether the amount of climate variability observed at Siple Dome is unique to Siple Dome, occurs at other coastal dome locations (i.e., Roosevelt Island), or is more widespread across the West Antarctic region (i.e., WAIS Divide). Understanding the amount of variability at an ice core location can better inform interpretations of climate signals seen in deep ice cores.

The Supplement related to this article is available online at doi:10.5194/cp-10-1253-2014-supplement.

Acknowledgements. The authors would like to thank the National Science Foundation for funding and support related to this project.

Edited by: J. Chappellaz 


\section{Appendix A: Cross-spectral wavelet analysis}

Plots of cross-spectral wavelet analysis (XWT) for shallow ice core $\delta \mathrm{D}$ records versus net accumulation, Niño 34, and SAM. The XWT changes one-dimensional time series into time-frequency space, creating a two-dimensional image of cross-modal variability and phase lag through time. The wavelet power is based on a red noise background spectrum. The phase arrows show the relative phasing of the time series (right: in-phase, left: anti-phase, down: $X$ leading $Y$ by $90^{\circ}$, up: $Y$ leading $X$ by $90^{\circ}$ ).
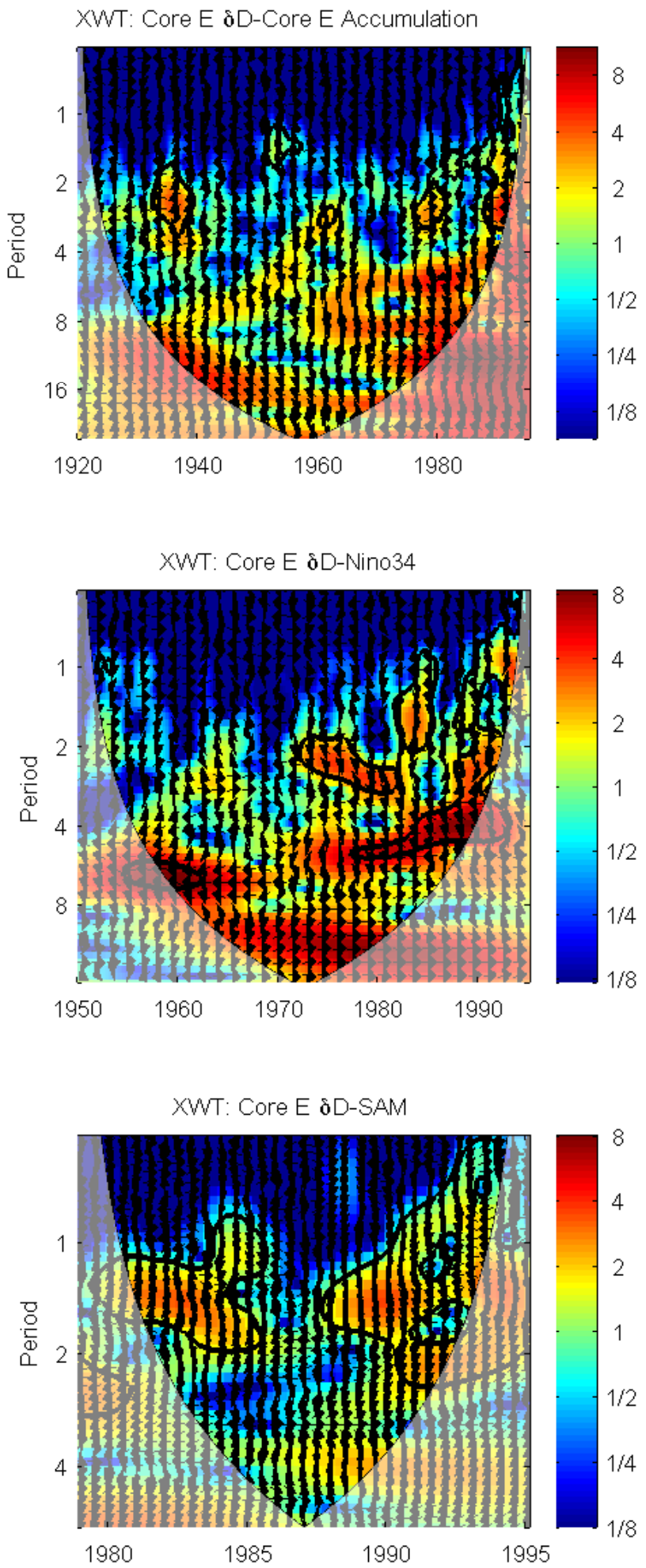

Figure A1. Top panel: core E $\delta \mathrm{D}$ and core E net accumulation XWT from 1657 to 1995 . Middle panel: core E $\delta \mathrm{D}$ and Niño $3.4 \mathrm{XWT}$ from 1950 to 1995 . Bottom panel: core $\mathrm{E} \delta \mathrm{D}$ and SAM XWT from 1979 to 1995 . 
XWT: Core G $\delta$ D-Core G Accumulation

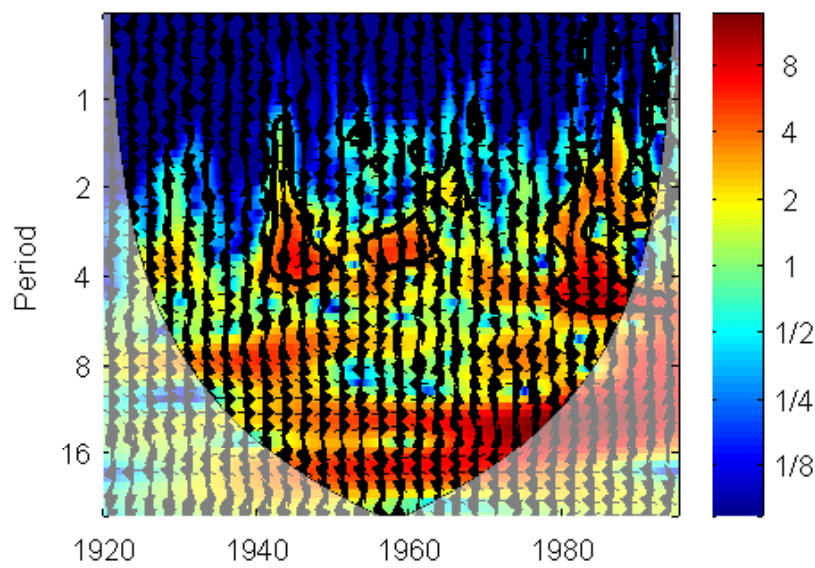

XWT: Core G oD-Nino34

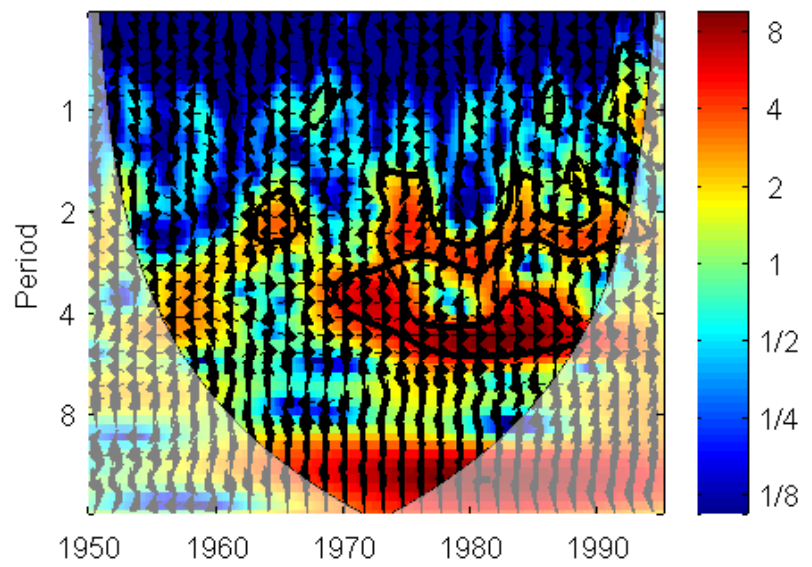

XWT: Core G $\delta$ D-SAM

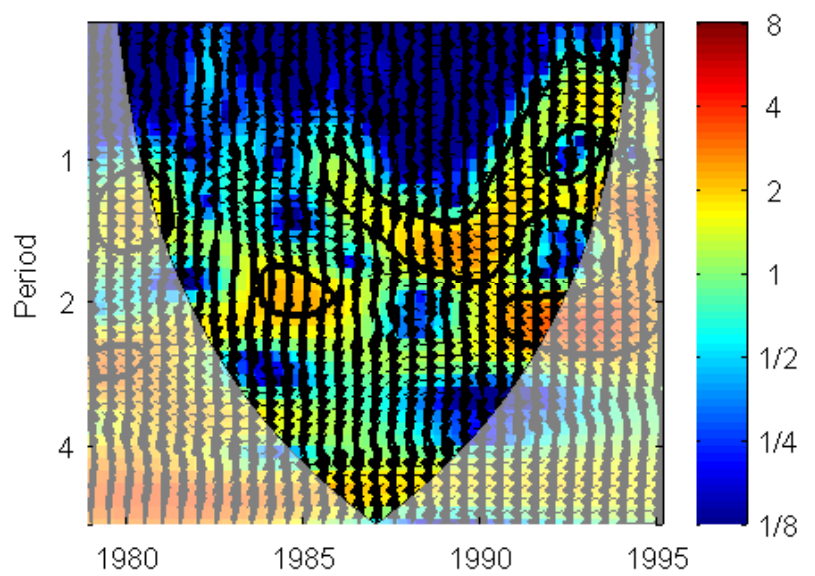

Figure A2. Top panel: core $\mathrm{G} \delta \mathrm{D}$ and core $\mathrm{G}$ net accumulation XWT from 1657 to 1995 . Middle panel: core $G \delta$ D and Niño 3.4 XWT from 1950 to 1995 . Bottom panel: core G $\delta$ D and SAM XWT from 1979 to 1995.
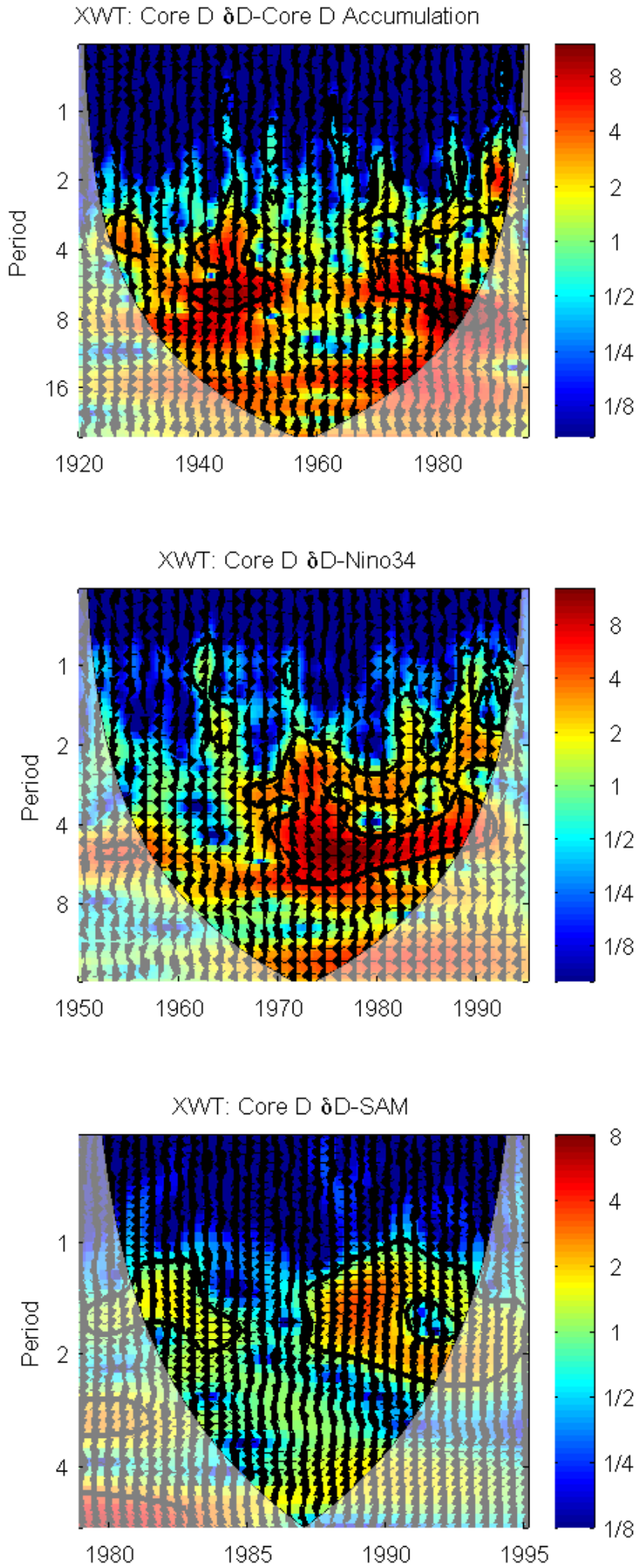

Figure A3. Top panel: core $\mathrm{D} \delta \mathrm{D}$ and core $\mathrm{D}$ net accumulation XWT from 1657 to 1995 . Middle panel: core D $\delta$ D and Niño 3.4 XWT from 1950 to 1995 . Bottom panel: core D $\delta$ D and SAM XWT from 1979 to 1995. 

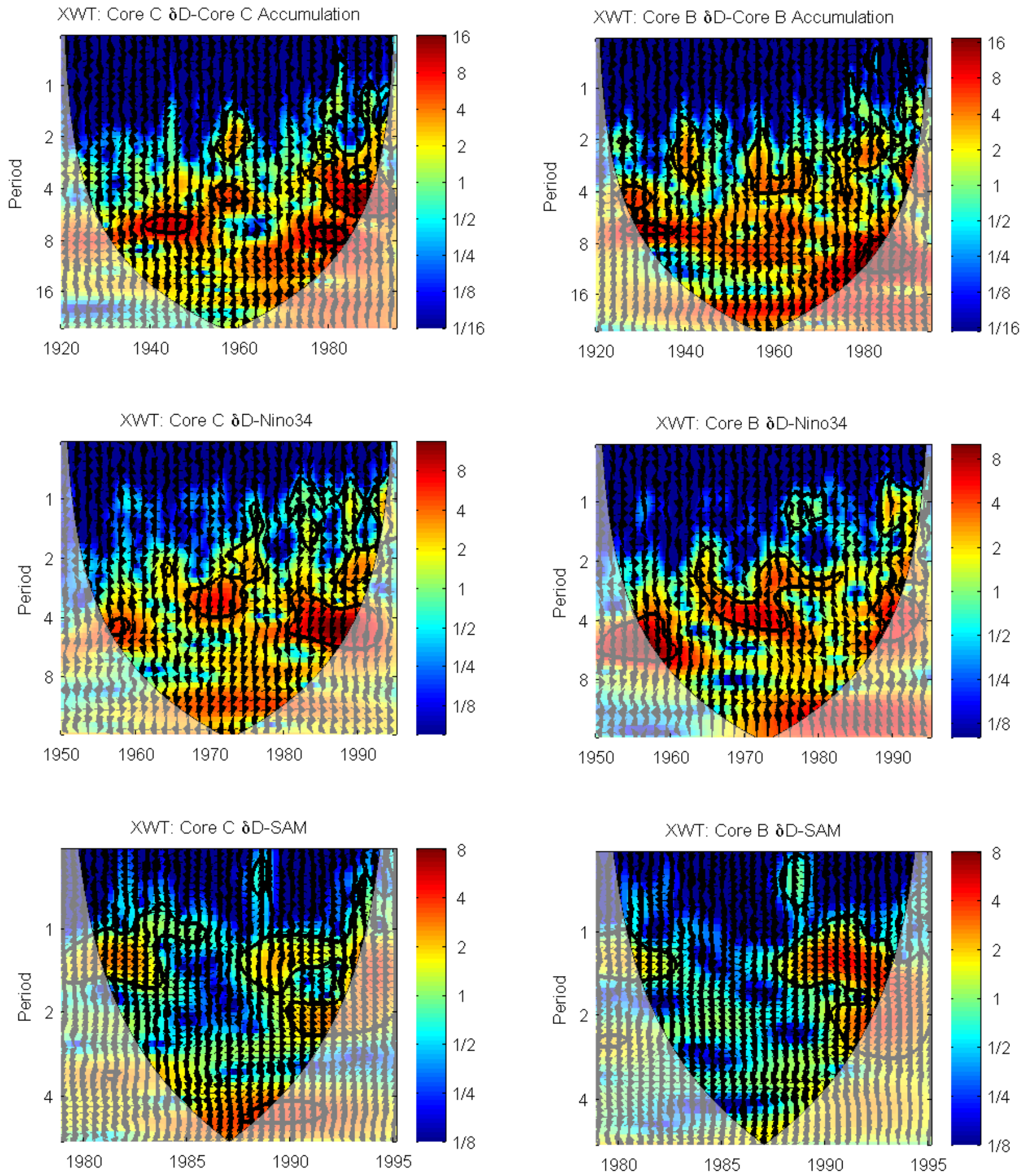

Figure A4. Top panel: core $\mathrm{C} \delta \mathrm{D}$ and core $\mathrm{C}$ net accumulation XWT from 1657 to 1995. Middle panel: core C $\delta \mathrm{D}$ and Niño 3.4 XWT from 1950 to 1995 . Bottom panel: core C $\delta$ D and SAM XWT from 1979 to 1995.

Figure A5. Top panel: core B $\delta \mathrm{D}$ and core $\mathrm{B}$ net accumulation XWT from 1657 to 1995 . Middle panel: core $\mathrm{B} \delta \mathrm{D}$ and Niño $3.4 \mathrm{XWT}$ from 1950 to 1995 . Bottom panel: core $\mathrm{B} \delta \mathrm{D}$ and SAM XWT from 1979 to 1995. 
XWT: Core $\mathrm{H} \delta \mathrm{D}$-Core $\mathrm{H}$ Accumulation

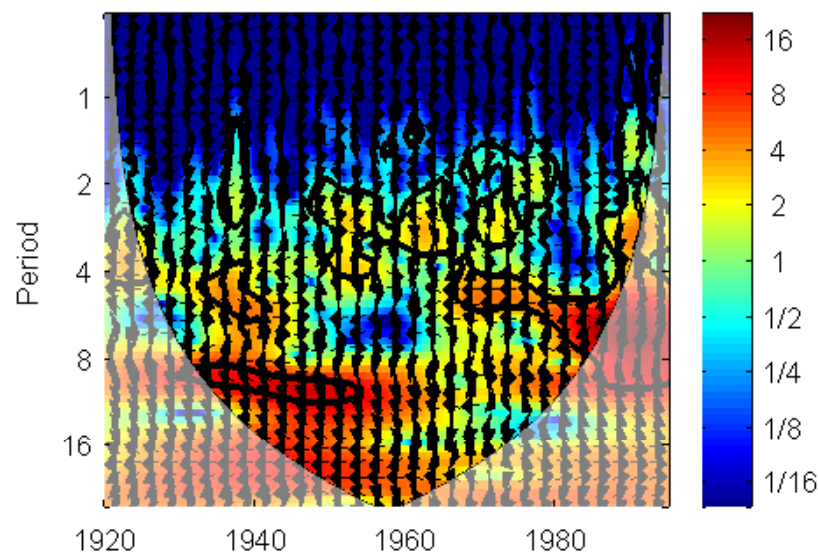

XWT: Core H \&D-Nino34
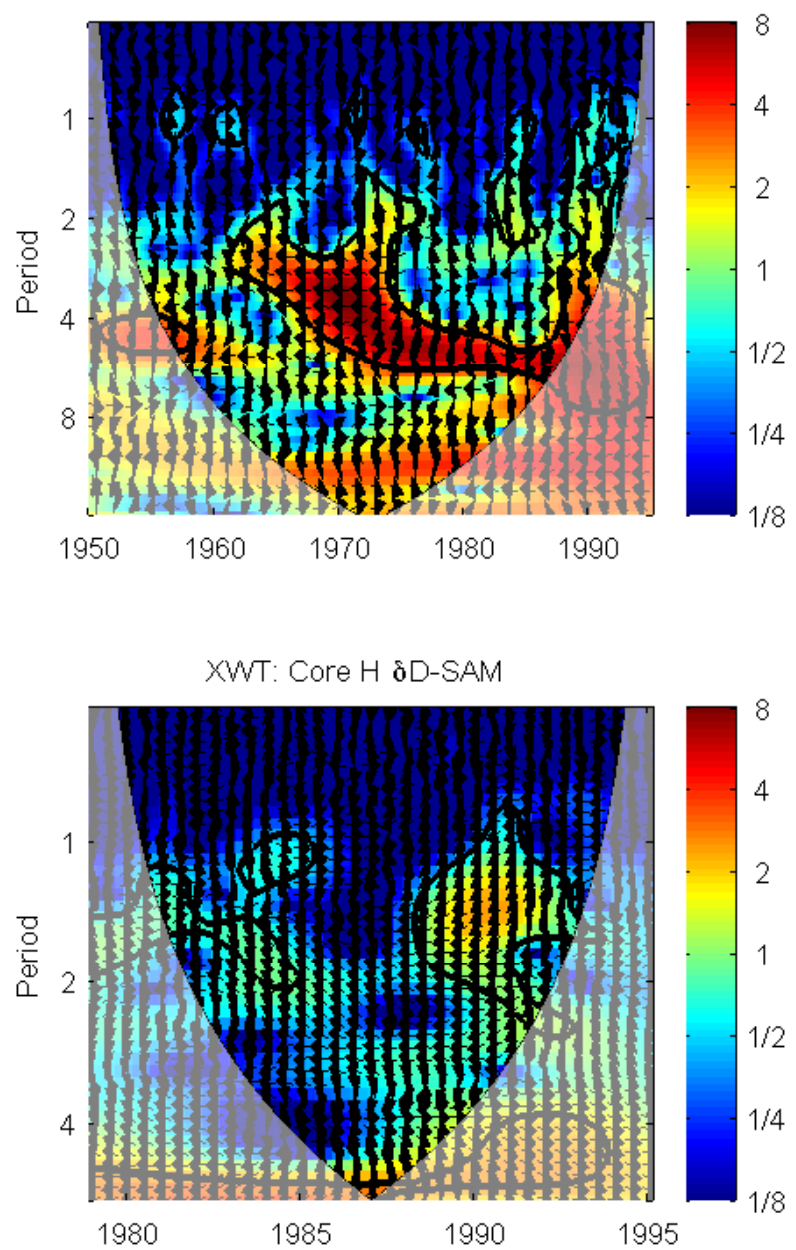

Figure A6. Top panel: core $\mathrm{H} \delta \mathrm{D}$ and core $\mathrm{H}$ net accumulation XWT from 1657 to 1995 . Middle panel: core $H \delta$ D and Niño 3.4 XWT from 1950 to 1995 . Bottom panel: core $\mathrm{H} \delta \mathrm{D}$ and SAM XWT from 1979 to 1995.
XWT: Core F $\delta$ D-Core F Accumulation
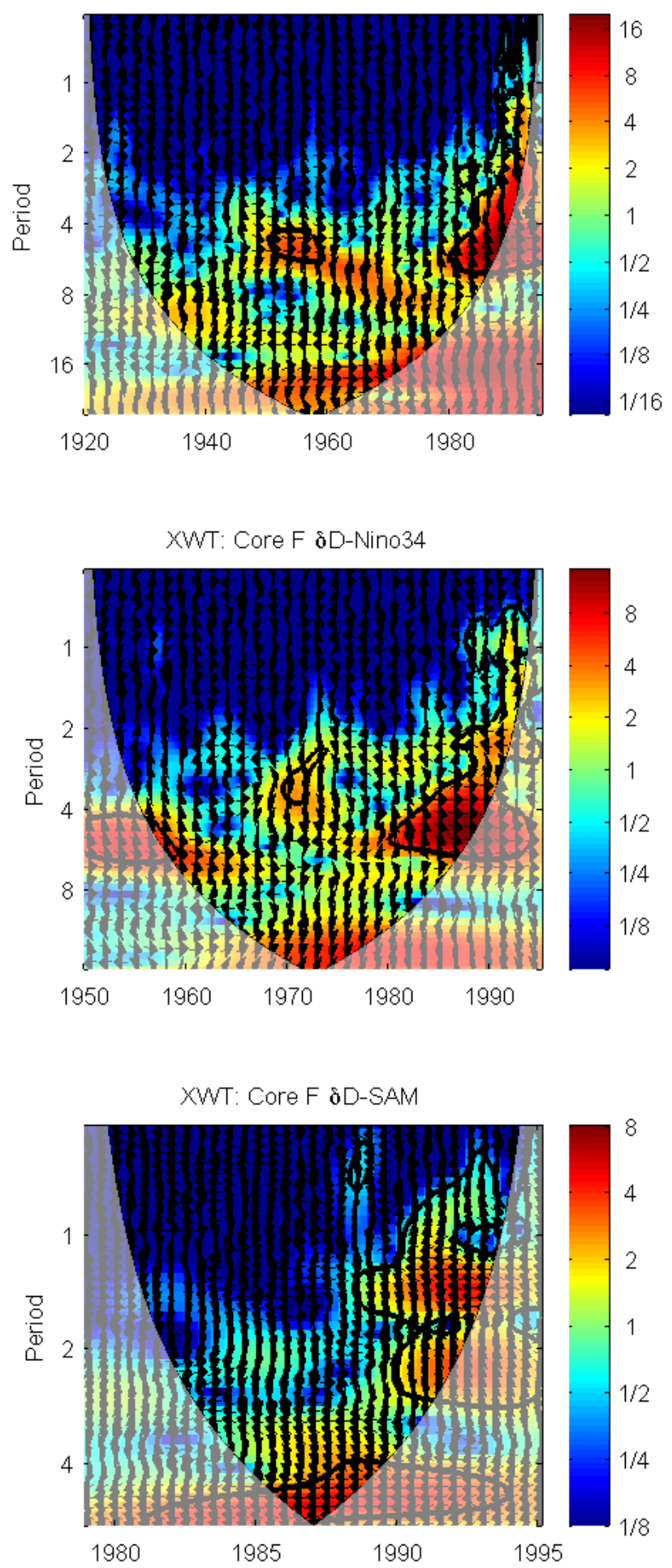

Figure A7. Top panel: core $\mathrm{F} \delta \mathrm{D}$ and core $\mathrm{F}$ net accumulation XWT from 1657 to 1995 . Middle panel: core $\mathrm{F} \delta \mathrm{D}$ and Niño $3.4 \mathrm{XWT}$ from 1950 to 1995 . Bottom panel: core $\mathrm{F} \delta \mathrm{D}$ and SAM XWT from 1979 to 1995. 


\section{References}

Alley, R.: Visible Stratigraphic Dating, Siple Dome and Upstream C Cores, http://nsidc.org/api/metadata?id=nsidc-0121, National Snow and Ice Data Center, Boulder, Colorado USA, 2003.

Bertler, N. A. N., Naish, T. R., Mayewski, P. A., and Barrett, P. J.: Opposing oceanic and atmospheric ENSO influences on the Ross Sea Region, Antarctica, Adv. Geosci., 6, 83-86, doi:10.5194/adgeo-6-83-2006, 2006.

Blunier, T., Chappellaz, J., Schwander, J., Dallenbach, A., Stauffer, B., Stocker, T. F., Raynaud, D., Jouzel, J., Clausen, H. B., Hammer, C. U., and Johnsen, S. J.: Asynchrony of Antarctic and Greenland climate change during the last glacial period, Nature, 394, 739-743, 1998.

Bromwich, D. H.: Snowfall in high southern latitudes, Rev. Geophys., 26, 149-168, 1988.

Bromwich, D. H., Carrasco, J. F., Liu, Z., and Tzeng, R.-Y.: Hemispheric Atmospheric Variations and Oceanographic Impacts Associated With Katabatic Surges Across the Ross Ice Shelf, Antarctica, J. Geophys. Res., 98, 13045-13062, 1993.

Bromwich, D. H., Monaghan, A., and Guo, Z.: Modeling the ENSO Modulation of Antarctic Climate in the Late 1990s with the Polar MM5, J. Climate, 17, 109-132, 2004.

Clow, G.: Siple Dome Shallow Ice Core Borehole Measurements, National Snow and Ice Data Center, Boulder, Colorado, USA, 1996.

Cuffey, K. M. and Steig, E. J.: Isotopic diffusion in polar firn: implications for interpretation of seasonal climate parameters in icecore records, with emphasis on central Greenland, J. Glaciol., 44, 273-284, 1998.

Dansgaard, W.: Stable Isotopes in Precipitation, Tellus, 16, 436468,1964

Delaygue, G., Masson, V., Jouzel, J., Koster, R. D., and Healy, R. J.: The origin of Antarctic precipitation: a modelling approach, Tellus B, 52, 19-36, 2000.

Ding, Q., Steig, E. J., Battisti, D. S., and Wallace, J. M.: Influence of the tropics on the Southern Annular Mode, J. Climate, 25, 63306348, 2012.

Ekaykin, A. A., Lipenkov, V. Y., Barkov, N. I., Petit, J. R., and Masson-Delmotte, V.: Spatial and temporal variability in isotope composition of recent snow in the vicinity of Vostok station, Antarctica: implications for ice-core record interpretation, Ann. Glaciol., 35, 181-186, 2002.

Epstein, S. and Mayeda, T.: Variation of O-18 Content of Waters from Natural Sources, Geochim. Cosmochim. Acta, 4, 213-224, 1953.

Fisher, D. A., Niels, R., and Clausen, H. B.: Stratigraphic noise in time series derived from ice cores, Ann. Glaciol., 7, 76-83, 1985.

Fogt, R. L. and Bromwich, D. H.: Decadal Variability of the ENSO Teleconnection to the High-Latitude South Pacific Governed by Coupling with the Southern Annular Mode, J. Climate, 19, 979997, 2006

Frezzotti, M., Urbini, S., Proposito, M., Scarchilli, C., and Gandolfi, S.: Spatial and temporal variability of surface mass balance near Talos Dome, East Antarctica, J. Geophys. Res., 112, F02032, doi:10.1029/2006JF000638, 2007

Grinsted, A., Moore, J. C., and Jevrejeva, S.: Application of the cross wavelet transform and wavelet coherence to geophysical time series, Nonlin. Processes Geophys., 11, 561-566, doi:10.5194/npg-11-561-2004, 2004.
Guo, Z., Bromwich, D., and Hines, K.: Modeled Antarctic Precipitation, Part II: ENSO Modulation over West Antarctica, J. Climate, 17, 448-465, 2004.

Hamilton, G. S.: Mass balance and accumulation rate across Siple Dome, West Antarctica, Ann. Glaciol., 35, 102-106, 2002.

Hendricks, M. B., DePaolo, D. J., and Cohen, R. C.: Space and time variation of $\delta^{18} \mathrm{O}$ and $\delta \mathrm{D}$ in precipitation: Can paleotemperature be estimated from ice cores?, Global Biogeochem. Cy., 14, 851861, 2000.

Hosking, J. S., Orr, A., Marshall, G. J., Turner, J., and Phillips, T.: The Influence of the Amundsen-Bellingshausen Seas Low on the Climate of West Antarctica and Its Representation in Coupled Climate Model Simulations, J. Climate, 26, 6633-6648, doi:10.1175/JCLI-D-12-00813.1, 2013.

Jouzel, J. and Merlivat, L.: Deuterium and O-18 In Precipitation - Modeling of the Isotopic Effect During Snow Formation, J. Geophys. Res.-Atmos., 89, 1749-1757, 1984.

Jouzel, J., Alley, R. B., Cuffey, K. M., Dansgaard, W., Grootes, P., Hoffman, G., Johnsen, S. J., Koster, R. D., Peel, D., Shuman, C. A., Stievenard, M., Stuiver, M., and White, J.: Validity of the temperature reconstruction from water isotopes in ice cores, J. Geophys. Res.-Oceans, 102, 26471-26487, 2007.

Kavanaugh, J. L. and Cuffey, K. M.: Space and time variation of $\delta^{18} \mathrm{O}$ and $\delta \mathrm{D}$ in Antarctic precipitation revisited, Global Biogeochem. Cy., 17, 1017, doi:10.1029/2002GB001910, 2003.

Lamorey, G. W.: Siple Shallow Core Density Data, http://nsidc.org/ api/metadata?id=nsidc-0129, National Snow and Ice Data Center, Boulder, Colorado, USA, 2003.

Masson-Delmotte, V., Hou, S., Ekaykin, A., Jouzel, J., Aristarain, A., Bernardo, R. T., Bromwich, D., Cattani, O., Delmotte, M., Falourd, S., Frezzotti, M., Gallée, H., Genoni, L., Isaksson, E., Landais, A., Helsen, M. M., Hoffmann, G., Lopez, J., Morgan, V., Motoyama, H., Noone, D., Oerter, H., Petit, J. R., Royer, A., Uemura, R., Schmidt, G. A., Schlosser, E., Simões, J. C., Steig, E. J., Stenni, B., Stievenard, M., van den Broeke, M. R., van de Wal, R. S. W., van de Berg, W. J., Vimeux, F., and White, J. W. C.: A Review of Antarctic Surface Snow Isotopic Composition: Observations, Atmospheric Circulation, and Isotopic Modeling, J. Climate, 21, 3359-3387, 2008.

Nereson, N. A., Raymond, C. F., Waddington, E. D., and Jacobel, R. W.: Migration of the Siple Dome ice divide, West Antarctica, J. Glaciol., 44, 643-652, 1998.

Nereson, N. A., Raymond, C. F., Jacobel, R. W., and Waddington, E. D.: The accumulation pattern across Siple Dome, West Antarctica, inferred from radar-detected internal layers, J. Glaciol., 46, 75-87, 2000.

Noone, D. and Simmonds, I.: Annular variations in moisture transport mechanisms and the abundance of $\delta^{18} \mathrm{O}$ in Antarctic snow, J. Geophys. Res., 107, 4742, doi:10.1029/2002JD002262, 2002.

Schneider, D., Steig, E., and Comiso, J.: Recent climate variability in Antarctica from satellite-derived temperature data, J. Climate, 17, 1569-1583, 2004.

Shimizu, H.: Glaciological studies in West Antarctica, 1960-1962, Antarct. Snow Ice Stud., 2, 37-64, 1964.

Steig, E. J. and White, J. W. C.: Siple Dome highlights: Stable isotopes, National Snow and Ice Data Center, Boulder, Colorado, USA, 2003. 
Thompson, D. W. J. and Wallace, J. M.: Annular Modes in the Extratropical Circulation. Part I: Month-to-Month Variability, J. Climate, 13, 1000-1016, doi:10.1175/15200442(2000)013<1000:AMITEC>2.0.CO;2, 2000.

Torrence, C. and Compo, G.: A practical guide to wavelet analysis, B. Am. Meteorol. Soc., 79, 61-78, 1998.

Trenberth, K. E. and Hoar, T. J.: El Niño and climate change, Geophys. Res. Lett., 24, 3057-3060, 1997.

Turner, J.: The El Niño-Southern Oscillation and Antarctica, Int. J. Climatol., 24, 1-31, 2004.
Turner, J., Phillips, T., Hosking, J. S., Marshall, G. J. and Orr, A.: The Amundsen Sea Low, Int. J. Climatol., 33, 1818-1829, doi:10.1002/joc.3558, 2012.

Vaughn, B. H., White, J. W. C., Delmotte, M., Trolier, M., Cattani, O., and Stievenard, M.: An automated system for hydrogen isotope analysis of water, Chem. Geol., 152, 309-319, 1998.

Zwally, H. J. and Gloersen, P.: Passive microwave images of the polar regions and research applications, Polar Rec., 18, 431-450, 1977. 